\title{
Effect of Nutrient Combinations on Growth, Yield and Quality of Mustard (Brassica juncea L.)
}

\author{
Undavalli Satyanarayana ${ }^{*}$, Rajesh Singh, Punnam Chhetri and Ekta Singh
}

Department of Agronomy, Sam Higginbottom University of Agriculture, Technology and Sciences, Prayagraj, Uttar Pradesh, India

*Corresponding author

\section{A B S T R A C T}

Keywords

Sulphur, Boron, Zinc, Mustard, CGR, RGR, Dry Weight

\section{Article Info}

\section{Accepted:}

14 January 2021 Available Online: 10 February 2021
A field experiment was conducted to determine the effect of sulphur, zinc and boron treatment combinations on plant growth, yield and its attributes on mustard at Central Crop Research Farm, Department of Agronomy, SHUATS, Prayagraj (U.P). The treatment combinations of the study were as sulphur $(0,30$ and 40 $\mathrm{kg} / \mathrm{ha})$ zinc $(0$ and $5 \mathrm{~kg} / \mathrm{ha})$ and boron $(0 \%$ and $0.2 \%$ spray) respectively. There were 12 treatments each replicated thrice. Addition of $40 \mathrm{Kg} \mathrm{S}$ along with $5 \mathrm{~kg} \mathrm{Zn}$ and $0.2 \%$ Boron spray resulted significant higher plant height (156.67), Dry weight $(11.81 \mathrm{~g})$, crop growth rate $(2.59)$ and relative crop growth rate $(0.05)$ at $100 \mathrm{DAS}$. Addition of $40 \mathrm{Kg} \mathrm{S}$ along with $5 \mathrm{~kg} \mathrm{Zn}$ and $0.2 \%$ Boron spray resulted significant higher test weight $(4.24 \mathrm{~g})$, seed yield $(1893.33 \mathrm{Kg} / \mathrm{ha})$, stalk yield $(3161.33 \mathrm{Kg} / \mathrm{ha})$ and oil content percentage (35.93).

\section{Introduction}

Indian mustard (Brassica juncea L.) a member of Brassicaceae family and an important oil seed crop of the world. Brassica contains many agriculturally important species, including vegetable, condiment, and oilseed crops.

The genetic relationships between six diploid and allopolyploid cultivated Brassica species were described by Nagaheru. The three diploids are B. rapa $(2 \mathrm{n}=20)$, B.nigra $(2 \mathrm{n}=$ $16)$, and B.oleracea $(2 \mathrm{n}=18)$ (Bayer, 2010).
The three allopolyploids are B. juncea $(2 \mathrm{n}=$ $36)$, B. napus $(2 \mathrm{n}=38)$, and B. carinata $(2 \mathrm{n}=$ 34), which have evolved as a result of hybridization between different mono genomic diploids. $B$. juncea (brown mustard, $2 \mathrm{n}=4 \mathrm{x}=36$ ) is an allotetraploid species evolved from a spontaneous hybridization of B. rapa and B. nigra (Bybordi \& Mamedov, 2010).

Mustard has primary center of its origin in central Asia with secondary centers in central and western China, eastern India, Burma and through Iran to Near East cultivated for 
centuries in many parts of Eurasia. However, the principal growing countries are Bangladesh, Central Africa, China, India, Japan, Nepal, and Pakistan, as well as southern Russia in north of the Caspian Sea (Kumar vineet et al., 2016).

Mustard seeds are excellent source of minerals such as magnesium, calcium, potassium and phosphorus. It is a great source of dietary folate and Vitamin A (Tripathi et al., 2010). Mustard leaves or greens are a great source of essential minerals such as calcium, potassium and phosphorus. It is a great source of dietary fiber and magnesium (Pandey et al., 2006).

The role of $S$ in plants is to help in the formation of plant proteins, and it is essential for the formation of chlorophyll and improves root growth. Sulphur is involved in the formation of vitamins and enzymes required for the plant to conduct its biochemical processes (Scherer et al., 2008). Sulphur deficiency in the soil can not only reduce grain yield and quality of produce but also make a sharp impact in agro-based economy (Fismesa et al., 2000). Sulphur is accumulated in plants in low concentrations compared to $\mathrm{N}$, but is an essential element as a constituent of proteins, cysteine-containing peptides such as glutathione, or numerous secondary metabolites (Kumar et al., 2012).

Boron plays a prominent role in diverse range of the plants functions including cell wall formation, stability, maintenance of structural and functional integrity of the biological membranes, movement of the sugar products in the plants from source to sink (Brown et al., 2002). Micronutrient Boron (B) has a prominent role in translocation of sugars, carbohydrate metabolism, flowering and regulation of hormones, acts as an activator of starch phosphorylase enzyme which is responsible for synthesis of starch and seed reserve substances. Foliar application of Boron improves fertilization and enhances the production and productivity of the oilseed legumes (Cara et al., 2002).

Zinc being one of the micronutrient, plays a significant role in the various enzymatic and physiological activities of the plant system. It is also essential for assimilation and $\mathrm{N}$ metabolism. It is important for stability of the cytoplasmic ribosome, cell division, dehydrogenase, proteinase, peptidase enzymes and helps in the synthesis of the protein and carotene (Das et al., 2005 and Pandey et al., 2006). $\mathrm{Zn}^{+2}$ deficiencies usually results in severe yield losses and in acute cases lead to the death of the crop plant. Kutuk et al., (2000) also suggested that the application of $\mathrm{Zn}$ has become necessary for improved crop yields. Mandal and Sinha (2004) recommended application of $\mathrm{ZnSO}_{4}$ at the rate of $20 \mathrm{~kg} / \mathrm{ha}$ for oilseeds including mustard.

\section{Materials and Methods}

The experiment was carried out during Rabi season of 2019 at Crop Research Farm, Department of Agronomy, Naini Agricultural Institute, SHUATS, Prayagraj (U.P).The soil of the experimental plot was sandy loam in texture, nearly neutral in soil reaction $(\mathrm{pH}$ $7.2)$, low in organic carbon ( $0.58 \%)$, medium in available $\mathrm{N}(238 \mathrm{Kg} / \mathrm{ha})$, high in available $\mathrm{P}(32.10 \mathrm{Kg} / \mathrm{ha})$ and low in available $\mathrm{K}(189$ $\mathrm{Kg} / \mathrm{ha}$ ). The treatment consisted of 3 levels of sulphur viz. $\mathrm{S}_{1}(0 \mathrm{Kg} \mathrm{S} / \mathrm{ha}), \mathrm{S}_{2}(30 \mathrm{Kg} \mathrm{S} / \mathrm{ha})$, $\mathrm{S}_{3}(40 \mathrm{Kg} \mathrm{S} / \mathrm{ha}), 2$ levels of Zinc $\mathrm{Z}_{1}(0 \mathrm{Kg} / \mathrm{ha})$ $\mathrm{Z}_{2}(5 \mathrm{Kg} / \mathrm{ha})$ and 2 levels of Boron $\mathrm{B}_{1}(0 \%$ spray $)$ and $\mathrm{B}_{2}(0.2 \%$ spray $)$ There are 12 treatments each replicated thrice. The experiment was laid out in Randomized Block Design. It was sown on $6^{\text {th }}$ December 2019 at spacing $45 \mathrm{~cm} \times 20 \mathrm{~cm}$ recommended doses of nitrogen and potassium were applied. 


\section{Results and Discussion}

The growth parameters like plant height, Dry weight of plant Crop growth rate and Relative growth rate were significantly affected by the application of sulphur,Boron and Zinc.

\section{Growth parameters}

\section{Plant height}

Mustard crop fertilized with40 $\mathrm{Kg} \mathrm{S}$ along with $5 \mathrm{~kg} \mathrm{Zn}$ and $0.2 \%$ Boron spray resulted significant increase in plant height $(156.67 \mathrm{cms})$ at 100 DAS. Sulphur, being the fourth major essential element helps in formation of proteins, enzymes, vitamins that has a crucial role in plant metabolic activities. Kumawat and Pthan (2002) observed the increased plant height to the control in the mustard. Zinc activates certain enzymes which helps to synthesis certain enzymes which had an active role in the metabolites and its by-products. Shailendra Kumar et al., (2018) observed the same on application of zinc to the mustard crop in konkan region.

\section{Dry weight}

Mustard crop fertilized with40 $\mathrm{Kg} \mathrm{S}$ along with $5 \mathrm{~kg} \mathrm{Zn}$ and $0.2 \%$ Boron spray resulted significant increase indry weight (11.81 g) at 100 DAS. Sulphur application to the legumes increases leaves per plant, dry weight, protein content and nutrient up taking capacity, Katiyar et al., (2014) observed gradual increase in dry weight on $\mathrm{S}$ application. The micronutrient $\mathrm{B}$ plays a major role in movement of energy or sugars in the growing parts of the plant provides cell stability which helps for increase in fresh and dry weights; Gopal et al., (2018) reported similar results with B application in mustard.

Table.1 Effect of Nutrient Combinations on Growth of Mustard at (100 DAS)

\begin{tabular}{|c|c|c|c|c|}
\hline Treatment Combinations & $\begin{array}{l}\text { Plant } \\
\text { Height } \\
(\text { cms) }\end{array}$ & $\begin{array}{c}\text { Dryweight } \\
\text { (g/plant) }\end{array}$ & $\begin{array}{c}\text { Crop } \\
\text { Growth } \\
\text { Rate } \\
\text { (g/m² } / \text { day) }\end{array}$ & $\begin{array}{c}\text { Relative } \\
\text { Growth } \\
\text { Rate } \\
\text { (g/g/day) }\end{array}$ \\
\hline$T_{1}: 0 \mathrm{Kg} \mathrm{S}+0 \mathrm{~kg} \mathrm{Zn}+$ Boron no spray & 124.33 & 9.98 & 1.84 & 0.03 \\
\hline$T_{2}: 0 \mathrm{Kg} \mathrm{S}+0 \mathrm{~kg} \mathrm{Zn}+0.2 \%$ Boron spray & 137.66 & 10.16 & 2.18 & 0.03 \\
\hline$T_{3}: 0 \mathrm{Kg} \mathrm{S}+5 \mathrm{~kg} \mathrm{Zn}+$ Boron no spray & 139.67 & 10.22 & 1.95 & 0.04 \\
\hline$T_{4}: 0 \mathrm{Kg} \mathrm{S}+5 \mathrm{~kg} \mathrm{Zn}+0.2 \%$ Boron spray & 134.33 & 10.52 & 2.28 & 0.03 \\
\hline$T_{5}: 30 \mathrm{Kg} \mathrm{S}+0 \mathrm{~kg} \mathrm{Zn}+$ Boron no spray & 139.67 & 9.85 & 2.31 & 0.04 \\
\hline$T_{6}: 30 \mathrm{Kg} \mathrm{S}+0 \mathrm{~kg} \mathrm{Zn}+0.2 \%$ Boron spray & 149.33 & 10.34 & 2.19 & 0.03 \\
\hline $\mathrm{T}_{7}: 30 \mathrm{Kg} \mathrm{S}+5 \mathrm{~kg} \mathrm{Zn}+$ Boron no spray & 146.67 & 10.74 & 2.15 & 0.03 \\
\hline$T_{8}: 30 \mathrm{Kg} \mathrm{S}+5 \mathrm{~kg} \mathrm{Zn}+0.2 \%$ Boron spray & 154.67 & 11.67 & 2.38 & 0.04 \\
\hline$T_{9}: 40 \mathrm{Kg} \mathrm{S}+0 \mathrm{~kg} \mathrm{Zn}+$ Boron no spray & 149.00 & 10.12 & 2.09 & 0.03 \\
\hline$T_{10}: 40 \mathrm{Kg} \mathrm{S}+0 \mathrm{~kg} \mathrm{Zn}+0.2 \%$ Boron spray & 151.33 & 10.46 & 2.17 & 0.03 \\
\hline$T_{11}: 40 \mathrm{Kg} \mathrm{S}+5 \mathrm{~kg} \mathrm{Zn}+$ Boron no spray & 153.23 & 11.57 & 2.30 & 0.03 \\
\hline$T_{12}: 40 \mathrm{Kg} \mathrm{S}+5 \mathrm{~kg} \mathrm{Zn}+0.2 \%$ Boron spray & 156.67 & 11.81 & 2.59 & 0.05 \\
\hline SEm \pm & 2.19 & 0.26 & 0.08 & - \\
\hline $\mathrm{CD}(\mathrm{P}=0.05)$ & 6.42 & 0.75 & 0.24 & - \\
\hline
\end{tabular}


Table.2 Effect of Nutrient Combinations on Yield of Mustard

\begin{tabular}{|c|c|c|c|}
\hline Treatment Combinations & $\begin{array}{l}\text { Test weight } \\
\text { (g) }\end{array}$ & $\begin{array}{l}\text { Seedyield } \\
\text { (Kg/ha) }\end{array}$ & $\begin{array}{l}\text { StalkYield } \\
\text { (Kg/ha) }\end{array}$ \\
\hline$T_{1}: 0 \mathrm{Kg} S+0 \mathrm{~kg} Z \mathrm{Zn}+$ Boron no spray & 2.76 & 1584.33 & 2477.01 \\
\hline $\mathrm{T}_{2}: 0 \mathrm{Kg} \mathrm{S}+0 \mathrm{~kg} \mathrm{Zn}+0.2 \%$ Boron spray & 2.91 & 1656.33 & 2919.67 \\
\hline $\mathrm{T}_{3}: 0 \mathrm{Kg} \mathrm{S}+5 \mathrm{~kg} \mathrm{Zn} \mathrm{+} \mathrm{Boron} \mathrm{no} \mathrm{spray}$ & 3.22 & 1692.83 & 2863.33 \\
\hline $\mathrm{T}_{4}: 0 \mathrm{Kg} \mathrm{S}+5 \mathrm{~kg} \mathrm{Zn}+0.2 \%$ Boron spray & 3.67 & 1724.33 & 2757.33 \\
\hline $\mathrm{T}_{5}: 30 \mathrm{Kg} \mathrm{S}+0 \mathrm{~kg} \mathrm{Zn} \mathrm{+} \mathrm{Boron} \mathrm{no} \mathrm{spray}$ & 3.62 & 1720.67 & 2763.33 \\
\hline$T_{6}: 30 \mathrm{Kg} \mathrm{S}+0 \mathrm{~kg} \mathrm{Zn}+0.2 \%$ Boron spray & 3.73 & 1785.33 & 2840.02 \\
\hline $\mathrm{T}_{7}: 30 \mathrm{Kg} \mathrm{S}+5 \mathrm{~kg} \mathrm{Zn}+$ Boron no spray & 3.78 & 1811.67 & 2941.67 \\
\hline$T_{8}: 30 \mathrm{Kg} \mathrm{S}+5 \mathrm{~kg} \mathrm{Zn}+0.2 \%$ Boron spray & 4.06 & 1879.67 & 2906.66 \\
\hline$T_{9}: 40 \mathrm{Kg} \mathrm{S}+0 \mathrm{~kg} \mathrm{Zn} \mathrm{+} \mathrm{Boron} \mathrm{no} \mathrm{spray}$ & 3.23 & 1706.01 & 2983.33 \\
\hline$T_{10}: 40 \mathrm{Kg} \mathrm{S}+0 \mathrm{~kg} \mathrm{Zn}+0.2 \%$ Boron spray & 3.86 & 1717.12 & 2860.04 \\
\hline$T_{11}: 40 \mathrm{Kg} \mathrm{S}+5 \mathrm{~kg} Z \mathrm{Zn}+$ Boron no spray & 3.93 & 1867.67 & 2971.67 \\
\hline$T_{12}: 40 \mathrm{Kg} \mathrm{S}+5 \mathrm{~kg} \mathrm{Zn}+0.2 \%$ Boron spray & 4.24 & 1893.33 & 3161.33 \\
\hline SEm \pm & 0.07 & 57.29 & 99.91 \\
\hline $\mathrm{CD}(\mathrm{P}=\mathbf{0 . 0 5})$ & 0.23 & 168.02 & 293.04 \\
\hline
\end{tabular}

Table.3 Effect of Nutrient Combinations on Oil Content of Mustard

\begin{tabular}{|c|c|}
\hline Treatment Combinations & Oil content $(\%)$ \\
\hline $\mathrm{T}_{1}: 0 \mathrm{Kg} \mathrm{S}+0 \mathrm{~kg} \mathrm{Zn}+$ Boron no spray & 32.07 \\
\hline $\mathrm{T}_{2}: 0 \mathrm{Kg} \mathrm{S}+0 \mathrm{~kg} \mathrm{Zn}+0.2 \%$ Boronspray & 33.04 \\
\hline $\mathrm{T}_{3}: 0 \mathrm{Kg} \mathrm{S}+5 \mathrm{~kg} \mathrm{Zn}+$ Boron no spray & 32.59 \\
\hline $\mathrm{T}_{4}: 0 \mathrm{Kg} \mathrm{S}+5 \mathrm{~kg} \mathrm{Zn}+0.2 \%$ Boronspray & 32.50 \\
\hline $\mathrm{T}_{5}: 30 \mathrm{Kg} \mathrm{S}+0 \mathrm{~kg} \mathrm{Zn}+$ Boron no spray & 33.02 \\
\hline $\mathrm{T}_{6}: 30 \mathrm{Kg} \mathrm{S}+0 \mathrm{~kg} \mathrm{Zn}+0.2 \%$ Boron spray & 34.03 \\
\hline $\mathrm{T}_{7}: 30 \mathrm{Kg} \mathrm{S}+5 \mathrm{~kg} \mathrm{Zn}+$ Boron no spray & 33.19 \\
\hline $\mathrm{T}_{8}: 30 \mathrm{Kg} \mathrm{S}+5 \mathrm{~kg} \mathrm{Zn}+0.2 \%$ Boron spray & 34.03 \\
\hline$T_{9}: 40 \mathrm{Kg} \mathrm{S}+0 \mathrm{~kg} \mathrm{Zn} \mathrm{+} \mathrm{Boron} \mathrm{no} \mathrm{spray}$ & 35.11 \\
\hline $\mathrm{T}_{10}: 40 \mathrm{Kg} \mathrm{S}+0 \mathrm{~kg} \mathrm{Zn}+0.2 \%$ Boronspray & 34.16 \\
\hline$T_{11}: 40 \mathrm{Kg} S+5 \mathrm{~kg} \mathrm{Zn}+$ Boron no spray & 35.06 \\
\hline $\mathrm{T}_{12}: 40 \mathrm{Kg} \mathrm{S}+5 \mathrm{~kg} \mathrm{Zn}+0.2 \%$ Boron spray & 35.93 \\
\hline SEm \pm & 0.48 \\
\hline
\end{tabular}

Crop growth rate $\left(\mathrm{g} / \mathrm{m}^{2} / \mathrm{day}\right)$ and Relative growth rate (g/g/day)

Mustard crop fertilized with40 $\mathrm{Kg} \mathrm{S}$ along with $5 \mathrm{~kg} \mathrm{Zn}$ and $0.2 \%$ Boron spray resulted significant increase in Crop growth rate and Relative growth rate (2.59) and (0.05) respectively at 100 DAS. Due to availability of micro nutrients $\mathrm{B}$ and $\mathrm{Zn}+2$, it enhanced translocation of nutrients, sugars during seedling phase and development phases of crop growth, which accelerated the metabolic and physiological activity of the plant. It helped to assimilate more amounts of nutrients, facilitated more photosynthesis process and ultimately increased the growth parameters viz. LAI, CGR and RGR. Similar results were obtained by Rana et al., (2005) and Malewar et al., (2009). 


\section{Test weight}

At harvest significantly higher test weight $(4.24 \mathrm{~g})$ was observed by fertilization of 40 $\mathrm{Kg} \mathrm{S}$ along with $5 \mathrm{~kg} \mathrm{Zn}$ and $0.2 \%$ Boron spray. Rao et al., (2013), Kumar vineet et al., (2016) reported that application of sulphur, zinc and boron significantly increased the yield attributes such as number of siliquae per plant, seeds per siliqua and test weight and ultimately increases in yield. Since, these are major nutrients for oilseeds; promoted rapid vegetative growth and branching, thereby, increasing flowering, sink size, fruit and seed setting.

\section{Yield}

Mustard crop fertilized with $40 \mathrm{Kg} \mathrm{S}$ along with $5 \mathrm{~kg} \mathrm{Zn}$ and $0.2 \%$ Boron spray resulted significant higher seed yield and stalk yield $(1893.33 \mathrm{Kg} / \mathrm{ha})$ and $(3161.33 \mathrm{Kg} / \mathrm{ha})$ respectively.

Rana et al., (2005), Gopal et al., (2018), Rao et al., (2013) and Jat and Mehra (2007) reported that the micro nutrients $\mathrm{Zn}^{+2}$ and $\mathrm{B}$ also play their significant role in the enzymatic activities, proteins synthesis and show effect on nutrient up taking capacity (Singh and Meena 2005). Application of these treatment combinations, might have increased the microbial activity in the root zone which helped to uptake more nutrients thus maintain the proper nutritional system. As a result, all the growth parameters yield and its attributes increased which raised the Harvest Index (\%) than that of control.

\section{Oil content $(\%)$}

Mustard crop fertilized with $40 \mathrm{Kg} \mathrm{S}$ along with $5 \mathrm{~kg} \mathrm{Zn}$ and $0.2 \%$ Boron spray resulted significant higher oil content percent (35.93). The increased oil content with sulphur may be due to synthesis of more glucosides, which produces sulphur rich amino acids like cysteine and methionine, thioglucoside and synthesis of amino acids ultimately increased the oil content in seed Shankar and Meena (2015).

In conclusion, it is inferred from the present investigation that application of $40 \mathrm{Kg} \mathrm{S}$ along with $5 \mathrm{~kg} \mathrm{Zn}$ and $0.2 \%$ Boron sprayin addition to the full doses of nitrogen and potassium is recommended for receiving higher growth and yield of Mustard.

\section{References}

Bayer, (2010).Bayer Sequence Genome of Canola. Bayer Crop Science: The BioenergSite, Retrieved 8 November, 2010.

Brown, P. H., Bellaloui, N., Wimmer, M. A., Bassil, E. S., Ruiz, J., Hu, H., Pfeffer, H., Dannel, F., Römheld, V., (2002). Boron in plant biology, Plant Biology, 4, 205-223.

Bybordi, A. \&Mamedov, G., (2010).Evaluation of application methods efficiency of zinc and iron for canola (Brassica napusL.).Notulae Scientia Biologicae, 2(1), 94-103.

Cara, A. F., Sanchez, E., Ruiz, J. M., Rornero, L., (2002). Is phenol oxidation responsible for the short-term effects of boron deficiency on plasma membrane permeability and function in squash roots.Plant Physiology and Biochemistry, 40, 853-858.

Das, K., Dang, R., Shivananda, T. N., Sur, P., (2005). Interaction between phosphorus and zinc on the biomass yield and yield attributes of the medicinal plant stevia (Stevia rebaudiana). Science World Journal, 5, 390-395.

Fismesa, J., P.C. Vong, A. Guckert, E. Frossard, (2000). Influence of sulfur on apparent $\mathrm{N}$-use efficiency, yield and quality of oilseed rape (Brassica napus L.) grown on a calcareous soil. Eur $J$ 
Agron., 12(2): 127-141.

Gopal M Gupta, Thomas GV A, Palaniswami C, and Dhanapal R, (2018). Coconut leaf vermiwash: a bio-liquid from coconut leaf vermicompost for improving the crop production capacities of soil. Curr. Sci. 98(9):12021210.

Jat J. R., and Mehra R. K.,(2007). Effect of sulphur and zinc on yield and macro nutrient content in and uptake by mustard on Haplusteps.Journal of Indian society of Soil Sciences 55:190195.

Katiyar, K., Kumar, R. and Trivedi, S. K., (2014).Effect of levels and sources of sulphur on yield, quality and nutrient uptake by mustard (Brassica junceaL.).Progressive Agriculture, An International Journal, 12:69-73.

Kumar vineet, Knadpal, Diwedi Ashish, SagarVipin Kumar, Kumar Vikasah and Sharma Dinesh Kumar, (2016).Effect of nitrogen and zinc fertilizers rates on growth, yield and quality of Indian mustard

(Brassica junceaL.).International Journal of Agricultural Sciences.8(6) 1031-1035.

Kumar, Raman and Trivedi, S.K., (2012).Effect of levels and sources of sulphur on yield, quality and nutrient uptake by mustard (Brassica junceaL.).Progr. Agric., 12(1): 69- 73.

Kumawat and Pthan., (2002). Effect of nitrogen and sulphur on growth, yield and nutrient uptale by Indian Mustard (Brassica junceaL.). Indian Journal of Agricultural Sciences, 81:145-149.

Kutuk C, Gökhan C, Abdullah B, Başkan O, (2000). Effect of Humic Acid on some soil properties.BildiriÖzetleri, Soil Science Department, Agricultural Faculty, Ankara University, 06110Ankara Turkey.

Kumawat and Pthan., (2002). Effect of nitrogen and sulphur on growth, yield and nutrient uptale by Indian Mustard (Brassica junceaL.). Indian Journal of Agricultural Sciences, 81:145-149.

Malewar G. U., Kate S. D., Walkar S. L., and Ismall S. K., (2001).Interaction effect of zinc and boron on growth and yield of mustard (Brassica junceaL.).Journal of Indian Society of Soil Sciences. 49(4):763-766.

Mandal, Sinha AC,(2004).Nutrient Management Effects on Light Interception, Photosynthesis, Growth, Dry-matter Production and Yield of Indian Mustard (Brassica junceaL.). J. Agronomy and Crop Sci., 55(4): 287291.

Pandey, S., Manoj, K.M., and Tripath, M.K.,(2006).Study of inheritance of erucic acid in Indian mustard (Brassica junceaL.)OctaJournal of Biosciences 1: 77-84.

Rana K. S., Rana D. S. and Gautam R. C., (2005).Influence of phosphorous, zinc and sulphur on growth, nutrient uptake and economics of Indian mustard (Brassica JunceaL.) under rain-fed condition.Indian Journal of Agronomy (50): 314-316.

Rao PR, Subrhamanyam D, Sailaja B, Singh RP, Ravichandran V, Rao GS, Swain P, Sharma SG, Saha S, Nadaradjan S, Reddy PJ, (2013). Influence of boron on spikelet fertility under varied soil conditions in rice genotypes. $J$ Plant Nutr,36:390-400.

Scherer, H.W., S. Pacyna, K.R. Spoth, M. Schulz, (2008). Low levels of ferredoxin, ATP, and leghemoglobin contribute to limited N2 -fixation of peas (PisumsativumL.) and alfalfa (Medicago sativa L.) under S deficiency conditions. BiolFert Soils, 44: 909- 916.

Shailendra Kumar, Alok Patel, TriyugiNath, Sudhanshuverma and Anurag Prajapathi, (2018). Response of sulphur and zinc nutrition on growth, yield 
attributes and yield of Rapeseed (Brassica napusL.) under upland soil of Vindhya region. Journal of Pharmacognosy and Phytochesmistry. SP-(1): 135-140.

Shankar, B. and Meena, K.C.,(2015). Nutrient management for enhancing the productivity of Indian mustard (Brassica juncea L.). Adv. Appl. Res.,7(1): $36-$ 41.

Singh P., Pantora N., Singh K. N., Panhat R. B., (2013).Interaction effect of sulphur and potassium on nutritional quality and profitability of brown sarason Brassica rapa. Var brown sarosan) template
kasmir.Indian Journal of Agronomy 58: 91-95.

Singh, A., Meena, N. L., (2005).Effect of nitrogen and sulphur on growth, yield attributes and seed of mustard in eastern plains of Rajasthan. Indian journal of Agronomy.49(3): 186-188.

Tripathi, M. K., Chaturvedi, S., Shukla, D. K. and Mahapatra, B. S., (2010). Yield performance and quality in Indian mustard (Brassica junceaL.)as affected by integrated nutrient management. Indian Journal of Agronomy. 55(20):138-142.

\section{How to cite this article:}

Undavalli Satyanarayana, Rajesh Singh, Punnam Chhetri and Ekta Singh. 2021. Effect of Nutrient Combinations on Growth, Yield and Quality of Mustard (Brassica juncea L.). Int.J.Curr.Microbiol.App.Sci. 10(02): 411-417. doi: https://doi.org/10.20546/ijcmas.2021.1002.048 